\author{
Jakub Petri \\ iD https://orcid.org/0000-0002-0584-470X \\ Jagiellonian University \\ Institute of Philosophy \\ kuba.petri@gmail.com
}

\title{
UNDER CONSTRUCTION: URBAN PRACTICES OF TERRAIN VAGUE IN UPPER SILESIA
}

\begin{abstract}
The Silesian conurbation consists of large amounts of terrains of uncertain status. Empty areas left after closed coal mines, ironworks, decommissioned working-class recreation zones or simply SLOAPS (Spaces Left Over After Planning) tend to be increasingly noticed by Silesian citizens nowadays and the experience of terrain vagues has become an important factor shaping their daily routine. The article covers the one, chosen distinct Silesian terrain vague location: the landscape park Żabie Doty (situated in municipalities of Bytom - Chorzów - Siemianowice Śląskie) in a quest to investigate the „unintentional landscape" as a place of different independent urban practices, undertaken by inhabitants. Terrain vague is being presented as an opportunity rather than a burden for a modern urban planning.
\end{abstract}

\section{Keywords:}

Silesia, wastelands, landscape aesthetics, unintentional landscape, terrain vague, urban practices "non-design" policy

\section{FORST \& HÜTTE}

A quick look at the old Prussian map from the beginning of the $\mathrm{XX}^{\text {th }}$ century reveals at once the correlation between extensively wooded grounds and new industrial zones, popping up in almost every Silesian district. The Forst $\&$ Hütte pattern seems to visually determine the quality of the whole Silesian landscape. Forst is the German synonym for Wald, which means ,the forest”, and is present in the early $\mathrm{XX}^{\text {th }}$ century Silesian naming, marking large, forested 
areas surrounding cities, eg. Myslovitzer Forst. The Hütte denotes the hut or cottage house, however it is also visible in the naming of industrial plants eg. Eisenhütte (,ironworks") or even in the names of whole districts, developed on the basis of old factories eg. Laurahütte. ${ }^{1}$ The Silesian writer Szczepan Twardoch draws attention to the fact of a specific transition that took place at the beginning of the $\mathrm{XX}^{\text {th }}$ century, both in the Silesian mentality and landscape. The process was determined by a passage from the culture of gradient, fluid spatial borders, cultivated in the local, old rural culture to strict, formal, geometric measures, performed in modern, industrial culture. ${ }^{2}$ Rethinking Twardoch's metaphors, one could say that the settlement process, taking place in Silesia during the whole $\mathrm{XX}^{\text {th }}$ century, was a shift between the opposites of nature and industrial culture, and those elements seem to still be extremely important for the local landscape theory.

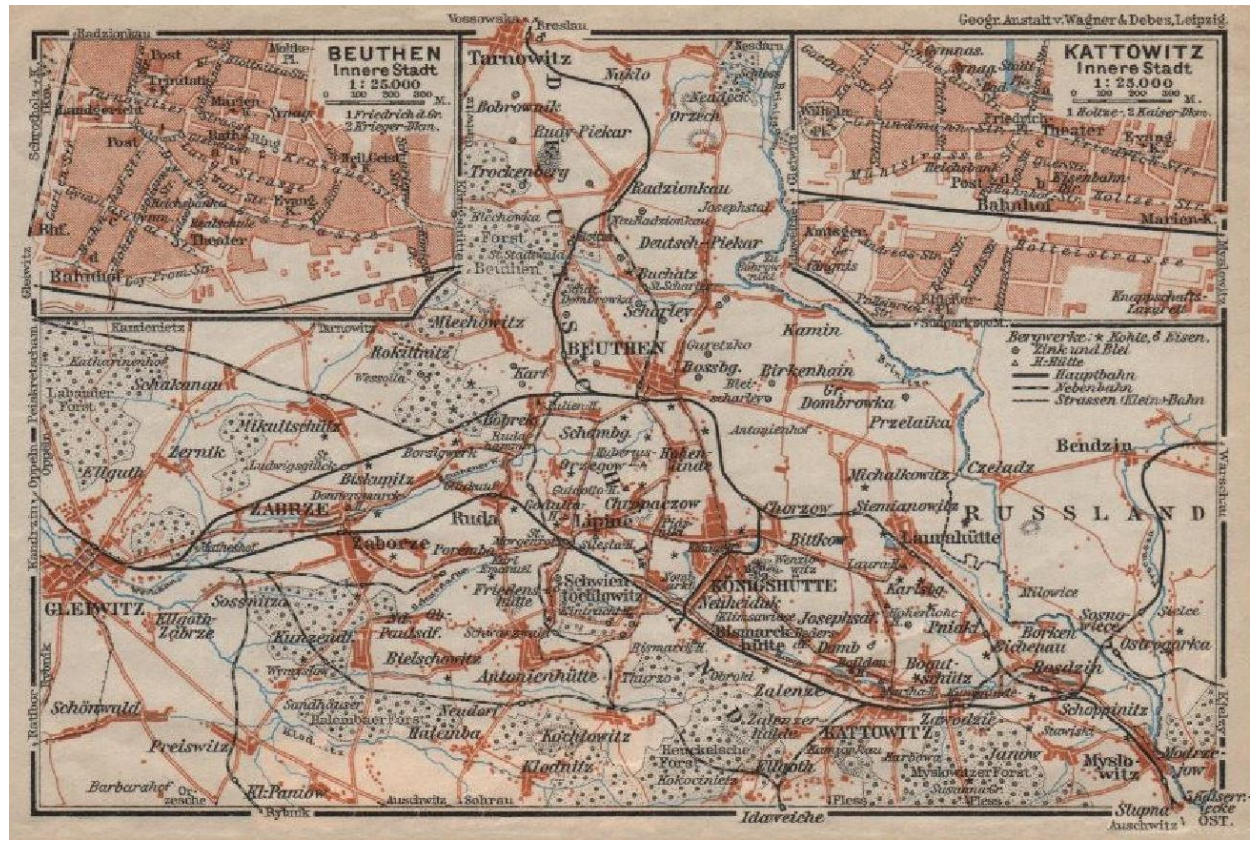

Fig. 1. The Prussian map of the Upper Silesia, 1910. Typical mix of nature and industry: forest (Germ. Forst) and ironworks (Germ. Hütte).

Source: Northern Germany as far as the Bavarian and Austrian frontiers: handbook for travelers (Leipzig: Karl Baedeker 1910), 409.

\footnotetext{
${ }^{1}$ Laurahütte - ironworks located in the center of the city of Siemianowice Sląskie, from which the informal name of the district was derived.

${ }^{2}$ Szczepan Twardoch, Drach (Kraków: Wydawnictwo Literackie, 2014).
} 


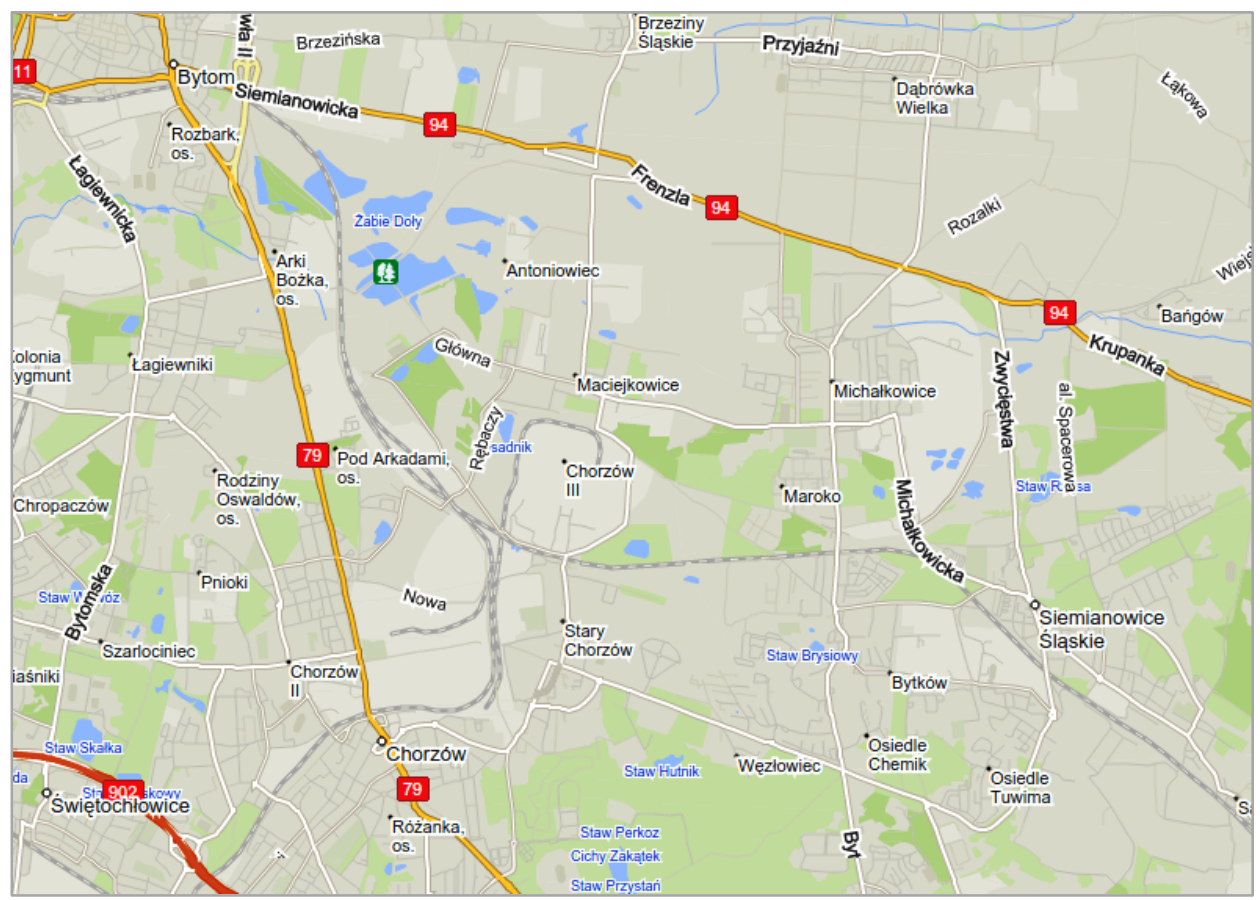

Fig. 2. Contemporary map of the territory between Silesian municipalities of Chorzów, Siemianowice Śląskie and Bytom including Park “Żabie Doły” [Frog Ditches].

Source: https://mapa.targeo.pl/18.9742547,50.3202431,23.

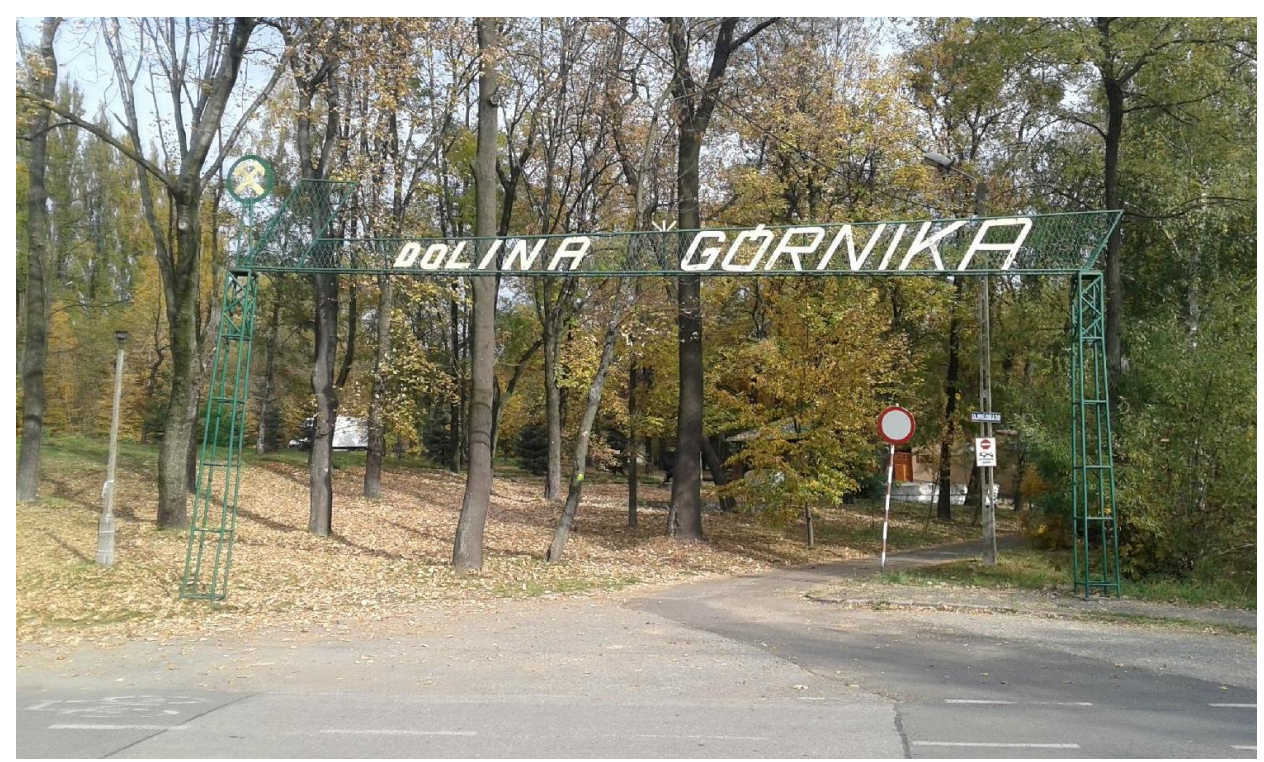

Fig. 3. Park "Dolina Górnika" [The Miner's Valley], the main entrance. Photo by Jakub Petri. 


\section{THE UNINTENTIONAL LANDSCAPE}

The overpresence of the so-called interstitial spaces seems to be specifically characteristic for modern Silesian conurbation, as its development was based, for more than one hundred years, on rapid industrialization and deindustrialization processes, of both organized and chaotic nature, that were taking place in relatively undetermined, mainly uninhabited, natural spaces. The lack of a strong, determining local urban context, but also the history of the region, created the possibility to act experimentally for planners and developers and resulted in at least four specific periods, shaping the Silesian landscape. ${ }^{3}$

- Prussian planning - up to 1919: based on the idea of patronage settlements for workers. ${ }^{4}$

- Polish and German state planning in 1922-1939: industrialization during the time when the eastern part of Upper Silesia became an autonomous province under the rule of Poland, and under conditions of trade war. ${ }^{5}$

- 1945-1989: socialist central planning. ${ }^{6}$

- 1989-today: deindustrialization and redevelopment of local identity. ${ }^{7}$

The result of the aforementioned processes is visible in the production of specific leftover, unfinished or decontextualized spaces. On that occasion, it is important to note, that during the last century, due to three local uprisings, World War II, socialism era and early period of Polish capitalism, Silesian citizens repeatedly lost their "city genetics," witnessing multiple processes of rapid restructuralization of their neighborhoods. ${ }^{8}$ The final, spatial effect of all those

\footnotetext{
${ }^{3}$ Most of modern Silesian cities are no older than 150 years. At the same time, there exist in Silesia a group of very old cities like Bytom (ger. Beuthen), however their number and area was not adequate to free spaces surrounding them and this old Sielsian urbanism could not provide the context for new settlements and industrial projects from the beginning of the XX the century.

${ }^{4}$ Eg. Gieschewald (Giszowiec) is the settlement based on Ebenezer Howards "the garden city" concept, designed and developed by Zillman brothers in vicinity of Katowice for the Giesche mining company.

${ }^{5}$ The period of the development of the proper Modernism in the area. Eg. modern style urbanism in the southern districts of Katowice.

${ }^{6}$ The period of the socialist realism. Eg. the great projects like WPKiW (Wojewódzki Park Kultury i Wypoczynku), the huge park planned in the scale of the whole province.

${ }^{7}$ The period of rapid deindustrialization and later modern urbanism, based on the idea of redeveloping local identity. Eg. "Strefa Kultury" - the culture zone in Katowice with its famous objects like NOSPR (The Polish National Radio Symphony Orchestra) building and the Silesian Museum.

8 "City genetics" is a technical term coined by Polish architect Tomasz Konior to describe a matrix of aesthetic relations between citizens and urban environment, which has been formed during centuries of urban development. According to Konior, we can speak about certain kind of "urban DNA", that is passed from generation to generation in the context of the local urban history. On Tomasz Konior concept of "city genetics" see: Jakub Petri, "Garden Cities of Katowice: A study of Cityholia," Art Inquiry: Recherches sur les Arts, vol. XVIII (2016).
} 
perturbations can be recognized in terms of a "non design" phenomenon. ${ }^{9}$ However, Gandy points out that "non design" spaces seem to construct even larger category of an "unintentional landscape:"

The presence of unintentional landscapes invites reflection on the difficulties in defining marginal or interstitial spaces, or indeed the concept of landscape itself. In some cases, so-called wastelands or terrain vague have been appropriated as spaces of adventure or discovery. In other cases, these anomalous spaces have been the focus of anxiety or disdain, or simply erased on account of their putative "emptiness" to make way for more lucrative forms of land use. In recent years however, fragments of spontaneous nature have been incorporated into landscape design, or even mimicked through the adoption of "wasteland aesthetic". Marginal spaces appear to transcend existing Eurocentric circuits of landscape discourse by offering multiple meanings and manifestations. Indeed, the cultural and scientific interest in these spaces lies precisely in their complexity and uncertainty. ${ }^{10}$

\section{PARK „ŻABIE DOŁY” AS AN UNINTENTIONAL LANDSCAPE}

There was certainly no significant intention to create landscape park in the triangle between municipalities of Chorzów, Siemianowice Śląskie and Bytom. In fact, after recognizing that the postindustrial area is highly polluted by zinc and lead waste, the authorities simply could not use these spaces for housing projects. The terrain consisting of artificial lakes (of square, triangular or oval shape), railway system, paths, small forests, causeways and slag heaps was labeled as a landscape park and under rather unclear conditions has become available to people for recreational purposes. Then, in 1997, the story of the official "revitalization" of the area begins (fig. 4, 5).

However, until 2018, the activity of the authorities was very limited, as it resulted only in preventing the entrance for cars, simply by putting large, concrete components in several strategic places. Due to the lack of space management, the nature had more than two decades to reshape the place and interact with man-made structures left over in the spot.

\footnotetext{
9 The "non design" category is used by Mathew Gandy to describe interstitial and marginal spaces in their ecological, environmental aspect. The "non design" effect in Silesia landscape is an organic product of historical and socio-political processes of urban space creation. Alternative vocabularies for wastelands that begin to move away from emphasis on their utilitarian characteristics include "edgelands", "interim spaces", "interstitial spaces", and especially the term terrain vague which is connected with radical architectonic discourse. The diverse alternative lexicon for marginal spaces also intersects with emerging ecological insights that seek to valorize specific forms of biodiversity or the serendipitous aesthetics effects of "non design." M. Gandy, "Marginalia: Aesthetics, Ecology and Urban Wastelands," Annals of the Association for American Geographers, 103, no. 6 (2013): 1302.

${ }^{10}$ Matthew Gandy, “Unintentional Landscapes," Landscape Research, 41, no. 4 (2016): 433.
} 
In fact, the actual location consists of two separated areas, divided from the former industrial zone: "Dolina Górnika" [The Miners Valley, fig. 3] and actual landscape park "Żabie Doły" [Frog Ditches, fig. 2]. Whereas the Valley is fully accessible and serves as a place for picnics and fishing, the carefully separated landscape park seems to lack the defined features. It was taken under protection however, due to the truly amusing fact of a rapid development of birds colonies, that took place in this severely polluted location. At present times, the terrain is inhabited by 129 species of birds, 76 of which are nesting in the area. Surprisingly, the local environment which recreated itself during the last two decades on 6 million tons of waste, consists now of diverse habitats, in which 251 species of plants have been observed, among them some protected ones (eg. hipphopae rhamoides). ${ }^{11}$ Based on these facts, it is not surprising, that the actual urban policy of neighbor cities is officially focused on the possibilities of reshaping the region into the fully protected natural reserve. In this context, however, it is important to recognize also the paradoxical nature of changes that have occurred in the area. Processes of revitalization of the place were mostly spontaneous, not "intentional," as that category belongs only to our human activities, and human, as a shaping factor, was absent there for more than twenty years. ${ }^{12}$ It is important then to note some serious claims concerning further human steps in the matter of revitalization of the spot. Gernot Böhme, pointing out the difference between aestheticization of nature (in the form of a classic bourgeois aesthetics) and ecology, stresses the fact, that to understand aesthetics as a part of ecology, it is necessary to recognize the latter in terms of communication structures. ${ }^{13}$ Transferring this demand on the already discussed ground, one could say, that the quality of the revitalization process lies in the course of the process itself, not in some possible human intervention, nor in the separation of natural life, but in the balance of the information system, containing both "human" and "natural" elements. At "Żabie Doły" park, this objective seems to be obtained till present, because thanks to the boundary conditions set already in the end of the previous century, the right balance between the two factors has been provided. It is important to note, that this complicated homeostasis was possible thanks to determinations ongoing at least, at three different levels.

\section{Level one: the terrain design}

The original terrain design of the landscape park „Żabie Doły”, consisting of grid of heaps, intersecting with railway sections, by viaducts, seems to determine the unique landscape experience based on polarity between geometry and irregular, natural forms.

\footnotetext{
${ }^{11}$ See https://www.bytom.pl/zespol-przyrodniczo-krajobrazowy-zabie-doly

${ }^{12}$ People were present there only as passers-by, visitors, not acting agents.

${ }^{13}$ Gernot Böhme, Filozofia i estetyka przyrody (Warszawa: Oficyna Naukowa, 2002), 44-45.
} 
Level two: functions

The terrain has been used due to rather non-invasive functions, such as leisure, ecological forms of communication (walking, cycling), and traditional net of transport, yet incorporated in the terrain setup (railway system).

\section{Level three: "aesthetic factor"}

The "non-design" policy let citizens to develop their own relations with the area, reflecting their inherited aesthetic patterns, appealing to a local model of an urban identity (city genetics).

\section{THE “TERRAIN VAGUE” IN PROGRESS}

It was a Catalan architect and philosopher Ignasi Solà-Morales, who coined the term terrain vague to describe a specific class of empty, abandoned areas in a city frame. Instead of following classical concepts, linking such spaces to a category of dystopia, Solà-Morales tended to perceive them as spaces of polarization, filled with series of interesting occurrences and possibilities. ${ }^{14}$ It is important to note, that the nature of these possibilities occurs rather not as an economical or social, but can be characterized more in terms of an individual, aesthetic experience. Terrain vague seems to work then as a paradox: a productive negative of the city, which creates a sphere of freedom and authenticity for a citizen. ${ }^{15}$ Members of the artistic collective called "Stalker" referred to such places as "actual territories" to stress the aspect of negotiation and transition of the terrain vague:

the actual territories constitute the built city's negative, the interstitial and the marginal, spaces abandoned or in the process of transformation. These are the removed lieux de la mémoire, the unconscious becoming of the urban systems, the spaces of confrontation and contamination between the organic and the inorganic, between nature and artifice [...] The term 'actual' indicates the process in which space comes to being. ${ }^{16}$

In this context, „Żabie Doły” landscape park can be recognized as a typical terrain vague location, which can be confirmed on three already mentioned levels of its existence (see fig. 4-10).

\footnotetext{
${ }^{14}$ Ignasi Solà-Morales, “Terrain Vague," in: Anyplace, ed. Cynthia C. Davidson, (Cambridge: MIT Press, 1995), 118-123.

${ }^{15}$ On a terrain vague concept as a space of somatic intervention see Francesco Careri, "Transurbance," in: Terrain Vague: Interstices at the Edge of the Pale, ed. Patrick Baron, Manuela Mariani (New York: Routledge, 2014).

${ }^{16}$ STALKER Manifesto [Lorenzo Lomito,1996], in: Francesco Careri, Walkscapes: Walking as an aesthetic practice, (Ames: Culicidae Architectural Press, 2018), 166.
} 
Nature vs geometry

The terrain design of "Żabie Doły" is the result of a radical intersection between natural elements (which have been constituting the place from centuries) and modern, industrial frame of regular, geometric arrangements (photos 3-9). For more than twenty years now, nature has been testing the limitations of the leftover industrial setup, creating the strong feeling of tension between organic powers and the withstanding man-made, geometric components. The remembrance of the region's bygone glory is balanced by the influence of nature: birds sneaking their nests and different species of plants popping up on heaps and viaducts. The old industrial setup seems to create a frame for spontaneous natural interventions.

\section{Noise vs silence}

At a first glance, functions attached to the area of the landscape park appear paradoxical. Apparently, there seems to exist a strong contradiction between leisure purposes and traditional, extremely noisy, railway communication system. Each fifteen minutes or even more often, the area is filled with extreme noise of coal transports heading to the railway station in the city of Bytom. However, just after seconds, the terrain is once again filled with delicate sounds of trees rustling and birds singing. The structure of the interval is still, as it is regulated by a strict railway timetable. Birds and other small animals inhabiting the space, obviously have learned how to coexist in such conditions and simply ignore the noise. What is more, the sonic rhythm of the area seems to appear also as "natural" for humans visiting the region. The obviousness of existence of bipolar experience, spread between the appreciation of nature and the world of human technology, seems to be a derivative from the original "Forst \& Hütte" aesthetic experience pattern, inherited from the previous generations as a part of local "urban genetics".

\section{Finished vs unfinished}

"Żabie Doły" area seems to appear both as a finished and unfinished space. For sure, its geometrical design, railway intersections and borders of surrounding cities, determine it to stay in the previous shape. However, the fate of the region remains uncertain. On the one side, due to its environmental qualities, local authorities insist on transforming it into a natural reserve. On the other, there have been recently conducted some serious revitalization works, which interfere with an idea of wildlife protection. Almost half million euro have been spent from the Operational Program of the Silesian Province (2014-2020) on works including planting new trees, installing road signs for bicycles and pedestrians (!) and redeveloping leisure infrastructure, such as barbecue sheds and benches. It is important to note however, that in parallel, there have been provided some other implementations, which appear as a step in a right direction. First of all, the net of original viaducts have been secured and made more accessible for passers-by. Secondly, the new idea of redeveloping organic pathways seems to fit perfectly, as it helps to sustain the ecological aspect of the space. 

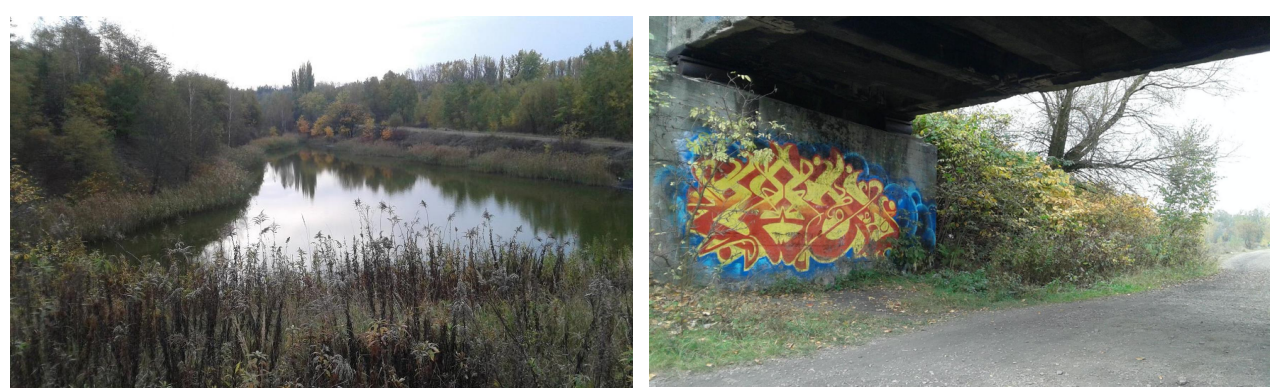

Fig. 4-5. "Żabie Doły", typical forms: tringular lakes, short paths built during the "revitalisation process" in 2018 (left), mix of paths, trees and railway system (right). Photo by Jakub Petri.

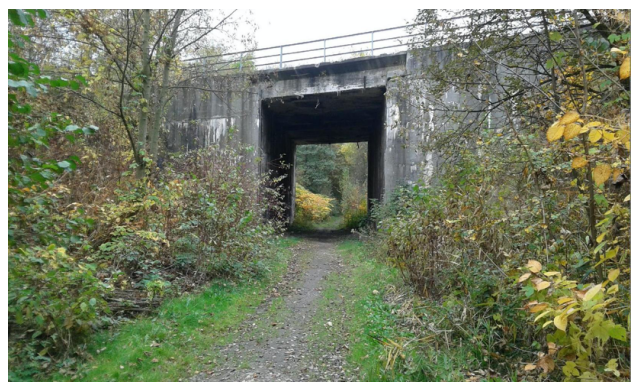

6. Above. "Żabie Doły", typical intersections of railway viaducts and natural paths. Photo by Jakub Petri.
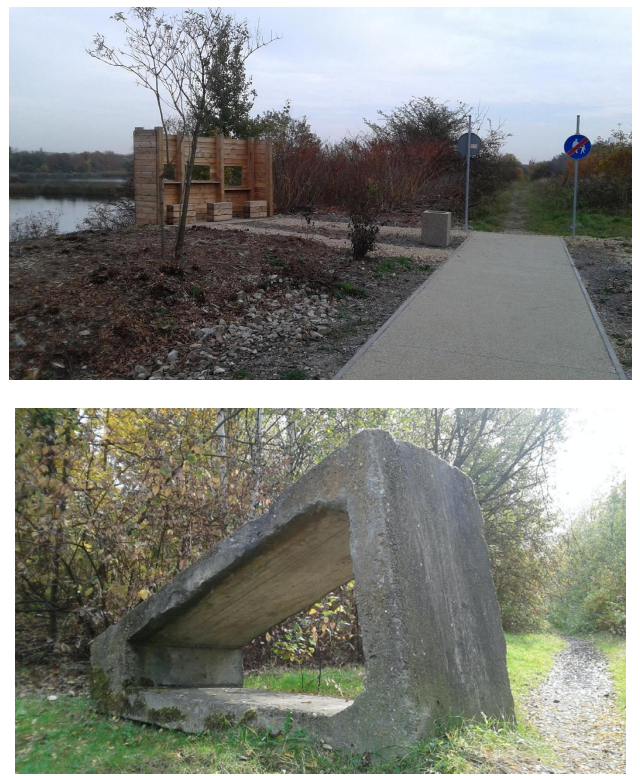

Fig. 9. "Żabie Doły," space still in progress: concrete geometric blocks guarding the terrain of future natural reserve. Photo by Jakub Petri.

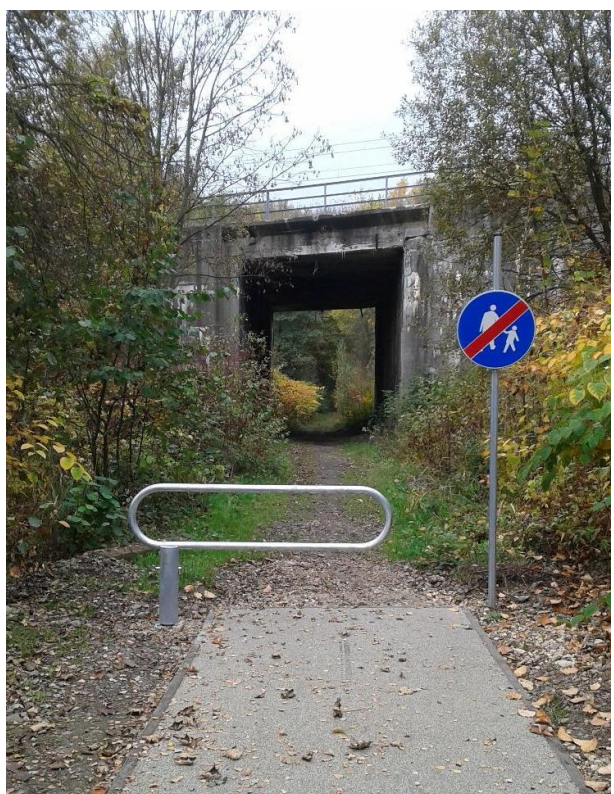

Fig. 7-8. Left and above. "Żabie Doły", examples of "revitalization process" absurdities. Photo by Jakub Petri.

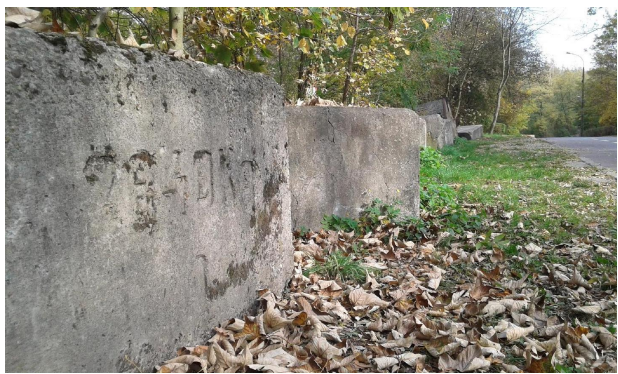

Fig. 10. Boundary between two areas: "Dolina Górnika" - the old recreation area for miners and the area of postulated nature reserve "Żabie Doły." Photo by Jakub Petri. 


\section{PROBLEMS AND SOLUTIONS}

One can ask, if once discovered, is there any future for the terrain vague? Of course, such spaces from their very nature appear as transitional and temporal. If, following the idea proposed by the Stalker group, we call them as "actual territories", our expectations should include the fact of their short duration. Although, this does not negate the sense of including such territories in urban planning. Paradoxical longevity of such terrain vague locations as famous "Alps" in Katowice proves a fact that in such cases, the less we care, the more we obtain. ${ }^{17}$ If we concentrate mainly on sustaining recognized qualities of the spot, it is very likely that even the next generation will enjoy visiting "Żabie Doły." However, if authorities and activists will follow a temptation of improving the space by investing funds into cultural performances and redevelopment of leisure infrastructure, there is no hope for sustaining the terrain vague status of the spot. The game is worth trying, as nowadays we are facing a lack of free spaces which let citizens to follow their inherited cultural habits and redevelop them into up-to-date lifestyles.

\section{BIBLIOGRAPHY}

Böhme Gernot. Filozofia i estetyka przyrody. Translated by Jarosław Marecki. Warszawa: Oficyna Naukowa, 2002.

Careri Francesco. Walkscapes: Walking as an aesthetic practice. Ames: Culicidae Architectural Press, 2018.

Gandy Matthew. "Marginalia: Aesthetics, ecology and Urban Wastelands." Annals of the Association for American Geographers, 103, no. 6 (2013): 1301-1316.

__. "Unintentional Landscapes." Landscape Research, 41, no. 4 (2016): 433-440.

Northern Germany as far as the Bavarian and Austrian frontiers: hand-book for travelers, Leipzig: Karl Baedeker, 1910.

Petri Jakub. "Garden Cities of Katowice: A Study of Cityholia." Art Inquiry: Recherches sur les Arts, vol. XVIII (2016): 127-143.

Solà-Morales Ignasi. “Terrain Vague.” In: Anyplace. Edited by Cynthia C. Davidson. Cambridge: MIT Press, 1995.

Terrain Vague: Interstices at the Edge of the Pale. Edited by Patrick Baron, Manuela Mariani.

New York: Routledge, 2014.

Twardoch Szczepan. Drach. Kraków: Wydawnictwo Literackie, 2014.

\footnotetext{
17 "Alps" is a neglected postindustrial area, located between the cities of Katowice and Siemianowice Śląskie. Yet in the 1970s., it was an illegal playscape for children from the surrounding blocks of flats. Some interesting photos show a famous Polish mountaineer Jerzy Kukuczka, collecting his first climbing experiences in the area.
} 